\title{
Publisher Correction: Accurate Detection of Dobutamine-induced Haemodynamic Changes by Kino- Cardiography: A Randomised Double-Blind Placebo-Controlled Validation Study
}

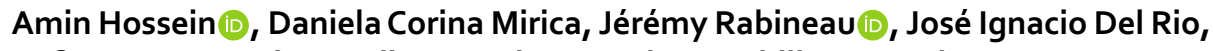
Sofia Morra, Damien Gorlier, Antoine Nonclercq, Philippe van de Borne \& Pierre-François Migeotte (iD)

Correction to: Scientific Reports https://doi.org/10.1038/s41598-019-46823-3, published online 19 July 2019

In the original version of this Article, the author Philippe van de Borne was incorrectly indexed. This error has now been corrected.

Open Access This article is licensed under a Creative Commons Attribution 4.0 International
License, which permits use, sharing, adaptation, distribution and reproduction in any medium or
format, as long as you give appropriate credit to the original author(s) and the source, provide a link to the Cre-
ative Commons license, and indicate if changes were made. The images or other third party material in this
article are included in the article's Creative Commons license, unless indicated otherwise in a credit line to the
material. If material is not included in the article's Creative Commons license and your intended use is not per-
mitted by statutory regulation or exceeds the permitted use, you will need to obtain permission directly from the
copyright holder. To view a copy of this license, visit http://creativecommons.org/licenses/by/4.0/.

(C) The Author(s) 2020 